\title{
TINJAUAN YURIDIS RAHASIA BANK TERHADAP SENGKETA HARTA BERSAMA DALAM PERCERAIAN PASCA PUTUSAN MAHKAMAH KONSTITUSI REPUBLIK INDONESIA NOMOR 64/PUU-X/2012
}

\author{
Oleh: \\ Muhammad Yasid \\ Universitas Darma AgunG, Medan \\ E-Mail : \\ yasidfakultashukum@gmail.com
}

\begin{abstract}
The Act No. 10 of 1998 about the Amendment of the Act No. 7 of 1992 about Banking in Article 40 Section (1) require banks to keep the information of the saving customers and their accounts, except in the rule as intended in Articles 41, 41A, 44, and 44A of Banking Law. With this exception, so the bank secret can only be opened when it meets the criteria of stipulation in this act that the parties who are not included in this exception do not have access to the secret, the Constitutional Court considers that this is against the 1945 Constitution of the Republic of Indonesia and it does not meet the justice for someone who wants to sue for the sharing of marriage joint property that the Constitutional Court of the Republic of Indonesia agree on the material testing for Banking Law in Article 40 Section (1). This causes new state of law that the Government and the House of People's Representative need to revise the formulation of Banking Law in Article 40 Section (1), which initially had two (2) articles becomes three (3) articles by adding one article, article 3, which says that the stipulation as intended in article (1) can be made into exception if it is for the interest of justice about joint property in the case of divorce.
\end{abstract}

\section{PENDAHULUAN}

Peranan perbankan sangat mempengaruhi kegiatan ekonomi suatu negara. Bank dapat dikatakan sebagai darahnya perekonomian suatu negara. Oleh karena itu, kemajuan suatu bank di suatu negara dapat pula dijadikan ukuran kemajuan negara yang bersangkutan. Semakin maju suatu negara maka semakin besar peranan perbankan dalam mengendalikan negaranya.

Bank suatu lembaga keuangan yang eksistensinya tergantung mutlak pada kepercayaan dari para nasabahnya yang mempercayakan dana simpanan mereka pada bank. Oleh karena itu, bank sangat penting menjaga kepercayaan masyarakat. Salah satu faktor untuk dapat memelihara dan meningkatkan rasa kepercayaan masyarakat terhadap suatu bank ialah kepatuhan bank terhadap kewajiban rahasia bank. Maksudnya dapat atau tidaknya bank dipercaya oleh nasabah yang menyimpan dananya pada bank tersebut untuk tidak mengungkapkan data simpanan nasabah, identitas nasabah tersebut kepada pihak lain. Dalam rangka menghindari terjadinya penyalahgunaan keuangan nasabah, maka dibuatlah aturan khusus yang melarang bank untuk memberikan informasi tercatat kepada siapapun 
berkaitan dengan keadaan keuangan nasabah, simpanan dan penyimpanannya sebagaimana diatur dalam Undang-Undang Nomor 10 Tahun 1998 tentang Perubahan Atas Undang Undang Nomor 7 tahun 1992 tentang Perbankan (untuk selanjutnya disebut Undang Undang Perbankan), kecuali dalam hal-hal tertentu yang disebutkan secara tegas didalam undang-undang tersebut. Hal inilah yang disebut dengan Rahasia Bank.

Bank dilarang memberikan keterangan yang tercatat pada bank tentang keadaan keuangan dan hal-hal lain dari nasabahnya, yang wajib dirahasiakan oleh bank menurut kelaziman dalam dunia perbankan, kecuali dalam hal sebagaimana dimaksud dalam Pasal 41, Pasal 41 A, Pasal 42, Pasal 43, Pasal 44 dan Pasal 44 A Undang Undang Perbankan.

Adanya ketentuan rahasia bank implikasinya bank dilarang memberikan keterangan atau informasi tentang keadaan keuangan dan hal-hal lain, hal ini dapat menimbulkan masalah baru bagi seorang istri atau suami yang ingin mencari keadilan dalam menuntut haknya pada harta yang timbul dalam perkawinannya, pada saat suami atau istri ingin menuntut haknya atas harta harta yang timbul dalam perkawinannya, ia harus bisa membuktikan harta harta apa saja yang timbul dalam perkawinannya tersebut. Karena Pasal 35 ayat 1 Undang-Undang Nomor 1 Tahun 1974 tentang Perkawinan dinyatakan, bahwa: "Harta benda yang diperoleh selama perkawinan menjadi harta berasama". Pengertian harta bersama adalah harta benda suami-istri yang didapatkan sama, atau suami saja yang bekerja dan istri tidak bekerja atau istri yang bekerja dan suami tidak bekerja.

Jadi dalam hal ini uang atau tabungan yang didapat selama perkawinan juga termaksud dalam harta bersama. Berkaitan dengan informasi perbankan bank dilarang memberikan keterangan atau informasi tentang keadaan keuangan dan hal-hal lain dari nasabahnya, walaupun simpanan nasabah tersebut termasuk bagian dari harta bersama, hal ini membuat seorang wanita di Banda Aceh mengajukan uji materi (judicial review) terhadap Pasal 40 ayat (1) Undang Undang Perbankan.

\subsection{Permasalahan}

1. Bagaimana ketentuan pengaturan rahasia bank terhadap harta bersama dalam Undang-Undang perbankan?

2. Bagaimana ketentuan pengaturan rahasia bank terhadap harta bersama dalam putusan Mahkamah Konstitusi Rpebublik Indonesia Nomor 64/PUU-X/2012?

\section{METODE PELAKSANAAN}

Suatu penelitian tidak dapat dikatakan penelitian apabila tidak memiliki metode penelitian karena tujuan penelitian adalah untuk mengungkapkan suatu kebenaran secara sistematis, metodologis, dan konsisten. Sebagaimana penelitian hukum yang merupakan suatu proses untuk menemukan aturan hukum, prinsip prinsip hukum, maupun dokrin-dokrin hukum yang berguna untuk menjawab isu hukum.

Dalam penelitian ini penulis menggunakan metode pendekatan yuridis normatif atau penelitian kepustakaan yaitu penelitian hukum dengan melakukan abstraksi melalui proses deduksi dari hukum positif yang berlaku, yang merupakan sistematis hukum dan sinkronisasi hukum secara horizontal terhadap penyelesaian masalah dalam pemberian informasi perbankan menyangkut harta bersama.

Data yang digunakan adalah data sekunder yang terdiri dari bahan 
hukum primer seperti Undang-Undang Nomor 10 Tahun 1998 tentang Perubahan Atas Undang-Undang Nomor 7 Tahun 1992 tentang Perbankan; Putusan Mahkamah Konstitusi Republik Indonesia Nomor 64/PUU-X/2012. bahan hukum sekunder seperti karya tulis buku yang relevan dengan penelitiana ini, dan bahan hukum tersier. Sementara teknik pengumpulan datanya melalui studi dokumen dengan penelusuran kepustakaan (library research). Setelah terkeumpul datanya maka akan diolah dan dinalisis secara kualitatif. Pengelolaan sumber bahan hukum hakikatnya kegiatan untuk mengadakan sistematika terhadap bahan-bahan hukum tertulis.Sistematika berarti membuat klarifikasi terhadap bahanbahan hukum tertulis tersebut untuk memudahkan pekerjaan, penafsiran, dan kontruksi.

\section{HASIL DAN PEMBAHASAN}

\section{Pengertian Bank}

Secara yuridis dalam Undang Undang Perbankan pada Pasal 1 angka 2 mendefinisikan bahwa "Bank adalah badan usaha yang menghimpun dana dari masyarakat dalam bentuk simpanan dan menyalurkannya kepada masyarakat dalam bentuk kredit dan atau bentuk bentuk lainnya dalam rangka meningkatkan taraf hidup rakyat banyak." Dalam kamus besar Bahasa Indonesia, kata "Bank" diartikan sebagai berikut: "Bank adalah lembaga keuangan yang usaha pokoknya memberi kredit dan jasa dalam lalu lintas pembayaran dan peredaran uang." Dari sudut pelayanan atau produk yang ditawarkan kepada konsumen, bank adalah institusi yang menerima simpanan dan menyalurkannya kepada masyarakat dalam bentuk pinjaman ataupun kredit. Sedangkan pengertian lembaga keuangan adalah setiap perusahaan yang bergerak dibidang keuangan dimana kegiatannya apakah hanya menghimpun dana atau hanya menyalurkan dana atau kedua-duanya.

Bank dapat dikatakan sebagai darahnya perekonomian suatu negara. Oleh karena itu, kemajuan suatu bank di suatu negara dapat pula dijadikan ukuran kemajuan negara yang bersangkutan. Semakin maju suatu, negara maka semakin besar peranan bank dalam mengendalikan negara tersebut.

\section{Pengertian Nasabah}

Nasabah merupakan konsumen dari pelayanan jasa perbankan, perlindungan konsumen baginya merupakan suatu tuntunan yang tidak boleh diabaikan begitu saja.dalam dunia perbankan pihak nasabah merupakan unsur yang sangat berperan bersandar kepada kepercayaan dari pihak masyarakat atau nasabah.

Nasabah dalam hubungannya dengan bank mempunyai kedudukan yang berada pada dua kriteria yang bisa bergantian sesuai pada saat mengadakan kontrak antara nasabah dengan bank. Dilihat dari sisi pengerahan dana, nasabah yang menyimpan dananya pada bank baik sebagai penabung, deposan, maupun pembeli surat berharga obligasi maka pada saat itu nasabah berkedudukan sebagai debitur dan bank sebagai kreditur. Dalam pelayanan jasa perbankan lainnya seperti pada pelayanan bank garansi, penyewaan save deposite box, transfer uang, dan pelayanan lainnya nasabah mempunyai kedudukan yang berbeda pula. Tetapi dari semua kedudukan tersebut pada dasarnya nasabah merupakan konsumen dari pelaku usaha yang menyediakan jasa disektor perbankan. Nasabah perbankan merupakan subjek hukum terdiri atas orang, badan dan badan hukum. 


\section{Pengertian Rahasia Bank}

Dalam Undang Undang
Perbankan pada Pasal 1 angka 28
mendefinisikan tentang Rahasia Bank adalah segala sesuatu yang berhubungan dengan keterangan mengenai nasabah penyimpanan dan simpanannya. Dalam hubungan ini yang menurut kelaziman wajib dirahasiakan oleh bank, adalah seluruh data dan informasi mengenai segala sesuatu yang berhubungnan dengan keuangan, dan hal-hal lain dari orang, dan badan yang diketahui oleh bank karena kegiatan usahanya. Dengan demikian, istilah rahasia bank mengacu kepada rahasia dalam hubungan antara bank dengan nasabahnya. Sedangkan rahasia-rahasia lain yang bukan merupakan rahasia antara bank dengan nasabah, sungguhpun juga bersifat rahasia tidak tergolong ke dalam istilah rahasia bank menurut Undang-Undang Perbankan. Rahasia-rahasia lain yang bukan rahasia bank tersebut, misalnya rahasia mengenai data dalam hubungan dengan pengawasan bank oleh Bank Indonesia, sebagaimana dimaksud dalam Pasal 30 dan Pasal 33 Undang Undang Perbankan. Undang Undang Perbankan Nomor 10 tahun 1998 mempertegas dan mempersempit pengertian rahasia bank dibandingkan dengan ketentuan dalam pasal-pasal dari undang-undang sebelumnya yaitu Undang-Undang Nomor 7 tahun 1992 tentang perbankan, yang tidak khusus pada deposan saja.

Berdasarkan pengertian dalam pasal 1 angka 28 dan pasal-pasal lainnya dapat ditarik unsur-unsur dari rahasia bank itu sendiri, yaitu: (a) Rahasia bank tersebut berhubungan dengan keterangan mengenai nasabah penyimpanan dan simpanannya. (b) Hal tersebut wajib dirahasiakan oleh bank, kecuali termasuk ke dalam kategori pengecualian berdasarkan prosedur dan peraturan perundang-undangan yang berlaku. (c) Pihak yang dilarang membuka rahasia bank adalah pihak bank sendiri dan/atau pihak terafiliasi.

\section{Pengertian Harta Bersama}

Bahwa dalam menjalani kehidupan harta mempunyai arti penting bagi seseorang karena dengan memiliki harta dia dapat memenuhi kebutuhan hidup secara wajar dan memperoleh status sosial yang baik dalam masyarakat. Padanan kata harta bersama terdiri dari dua kata yakni harta dan bersama. Dalam kamus besar bahasa Indonesia harta dapat berarti barangbarang (uang dan sebagainya) yang menjadi kekayaan dan dapat berarti kekayaan berwujud dan tidak berwujud yang bernilai. Harta bersama berarti harta yang dipergunakan (dimanfaatkan) secara bersama-sama.

Sayuti Thalib dalam bukunya hukum kekeluargaan di Indonesia mengatakan bahwa: "harta bersama adalah harta kekayaan yang diperoleh selama perkawinan diluar hadiah atau warisan". Maksudnya adalah harta yang didapat atas usaha mereka atau sendirisendiri selama masa perkawinan.

Secara yuridis pengertian harta bersama diatur pada Pasal 35 ayat (1) Undang Undang Nomor 1 Tahun 1974 tentang Perkawina mendefinisikan, bahwa: harta benda yang diperoleh selama perkawinan menjadi harta bersama. Berdasarkan pasal ini, secara yuridis formal dapat dipahami pengertian harta bersama adalah harta benda suami-istri yang didapatkan selama perkawinan. Yang mendapatkan bisa suami-istri secara bersama-sama, atau suami saja yang bekerja dan istri tidak bekerja atau istri yang bekerja dan suami tidak bekerja, tidak ditentukan yang mendapatkan harta, melainkan harta itu diperoleh selama perkawinan. Jadi sangat jelas dan tegas hukum menentukan bahwa harta yang diperoleh 
sebelum perkawinan bukanlah harta bersama.

\section{Pengertian Mahkamah Konstitusi Republik Indonesia}

Pengertian

Mahkamah

Konstitusi Republik Indonesia (untuk selanjutnya disebut disingkat MKRI) sebagaimana yang dikutip dari wikipedia menyebutkan bahwa Mahkamah Konstitusi Republik Indonesia adalah lembaga tinggi negara dalam sistem ketatanegaraan Indonesia yang merupakan pemegang kekuasaan kehakiman bersama sama dengan Mahkamah Agung. MKRI sebagai pemegang kekuasaan kehakiman dalam perubahan ketiga Undang Undang Dasar Negara Republik Indonesia tahun 1945 pada Pasal 24 C meneybutkan bahwa:

(1)Mahkamah Konstitusi berwenang mengadili pada tingkat pertama dan terakhir yang putusannya bersifat final untuk menguji undang-undang terhadap UndangUndang Dasar, memutuskan sengketa kewenangan lembaga negara yang kewenangannya diberikan oleh Undang-Undang Dasar, memutuskan pembubaran partai politik dan memutuskan perselisihan tentang hasil pemilihan umum.

(2)Mahkamah Konstitusi wajib memberikan putusan atas pendapat Dewan Perwaklian Rakyat mengenai dugaan pelanggaran oleh Presiden dan/atau Wakil Presiden menurut Undang-Undang Dasar.

(3)Mahkamah Konstitusi mempunyai sembilan orang anggota hakim konstitusi yang ditetapkan oleh Presiden, yang diajukan masingmasing tiga orang oleh Mahkamah Agung, tiga orang oleh Dewan Perwakilan Rakyat, dan tiga orang oleh Presiden.

(4)Ketua dan Wakil Ketua Mahkamah Konstitusi dipilih dari dan oleh Hakim Konstitusi.

(5)Hakim Konstitusi harus memiliki integritas dan kepribadian yang tidak tercela, adil, negarawan yang menguasai konstitusi dan ketatanegaraan, serta tidak merangkap sebagai pejabat negara.

(6)Pengangkatan dan pemberhentian hakim konstitusi, hukum acara serta ketentuan lainnya tentang Mahkamah Konstitusi diatur dengan undang-undang.

MKRI merupakan salah satu lembaga konstitusi yang melakukan kekuasaan kehakiman yang merdeka untuk menyelenggarakan peradilan guna menegakkan hukum. Lembaga MKRI ini mempunyai sembilan orang hakim konstitusi yang ditetapkan dengan keputusan presiden. Susunan Mahkamah Konstitusi terdiri atas seorang ketua merangkap anggota, seorang wakil ketua merangkap anggota dan tujuh orang Hakim Konstitusi. Pengaturan kewenganan dan hal berkaitan dengan MKRI diatur dalam Undang Undang Republik Indonesia Nomor 8 tahun 2011 tentang Perubahan Atas Undang Undang Nomor 24 tahun 2003 tentang Mahkamah Konstitusi Republik Indonesia.

\section{RAHASIA BANK TERHADAP HARTA BERSAMA DALAM UNDANG-UNDANG PERBANKAN}

Hubungan hukum antara bank dengan nasabah ada dua yaitu hubungan kontraktual dan hubungan non kontraktual dalam kedua hubungan tersebut bank mempunyai kewajiban untuk tidak mengungkapkan keterangan mengenai nasabah. Kewajiban untuk 
tidak mengungkapkan keterangan mengenai nasabah dalam hubungan kontraktual antara bank dengan nasabah timbul pada saat nasabah menandatangani formulir yang berisi perjanjian baku dengan klausula yang melarang bank untuk mengungkapkan keterangan mengenai nasabah sebab sejak ditandatanganinya formulir yang berisi perjanjian baku, perjanjian tersebut mengikat pihak bank dan nasabah untuk mematuhi klausulaklausula yang telah disepakati di dalam perjanjian atau kontrak antara bank dengan nasabahnya. Persetujuan itu tidak dapat ditarik kembali selain dengan kesepakatan kedua belah pihak, atau karena alasan-alasan yang ditentukan oleh undang-undang.

Jadi dalam hal ini apabila bank mengungkapkan keterangan mengenai nasabah kepada orang lain tanpa izin atau kuasa dari nasabah, maka bank tersebut dapat digugat oleh nasabah. Adanya aturan untuk menjaga kerahasian yang lahir dari hubungan perjanjian atau kontrak antara bank dengan nasabahnya diartikan bahwa bank mempunyai kewajiban untuk merahasiakan keterangan terhadap data nasabah maupun data simpananya. Hal ini berkesesuaian dengan ketentuan Pasal 1339 KUHPerdata yang menyebutkan: persetujuan tidak hanya mengikat untuk hal-hal yang dengan tegas dinyatakan didalamnya, tetapi juga untuk segala sesuatu yang menurut sifat persetujuan diharuskan oleh kepatutan, kebiasaan atau undangundang.

Selanjutnya hubungan bank dengan nasabah yaitu hubungan non kontraktual dalam hubungan tersebut terdapat pula kewajiban bagi bank untuk tidak membuka rahasia nasabahnya kepada pihak manapun kecuali jika ditentukan lain oleh perundang-undangan yang berlaku.
Kewajiban untuk tidak buka rahasia mengenai nasabah dalam hubungan non kontraktual ini lahir karena undang undang, dalam Peraturan perundangundangan yaitu pada Pasal 40 Undang Undang Nomor 10 Tahun 1998 tentang Perubahan Atas Undang Undang Nomor 7 tahun 1992 tentang Perbankan, yang mana dalam undang undang ini mengandung prinsip kerahasiaan yaitu suatu aturan yang mengharuskan atau mewajibkan bank merahasiakan segala sesuatu yang berhubungan dengan keuangan dan lain-lain dari nasabah bank yang menurut kelaziman dunia perbankan wajib dirahasiakan. Kerahasiaan ini adalah untuk kepentingan bank sendiri karena bank memerlukan kepercayaan masyarakat yang menyimpan uangnya di bank.

Pasal 40 Undang-Undang

Perbankan secara tegas membatasi kedudukan nasabah yang wajib dirahasiakan keterangannya, yakni hanya nasabah penyimpan. Penjelasan Pasal 40 ditegaskan, bilamana nasabah bank adalah nasabah penyimpanan yang sekaligus juga sebagai nasabah debitur, bank wajib tetap merahasiakan keterangan tentang nasabah dalam kedudukannya sebagai nasabah penyimpanan. Keterangan mengenai nasabah selain sebagai nasabah penyimpan, bukan merupakan keterangan yang wajib dirahasiakan oleh bank.

Pengaturan rahasia bank sebagai ketentuan pidana sebagaimana tercantum didalam Pasal 47 ayat (2) Undang-Undang Perbankan yang mengatur pelanggaran ketentuan rahasia bank yang menyangkut keadaan keuangan individual nasabah bank sebagai pelanggaran pidana biasa bukan delik aduan. Menurut sistem UndangUndang Perbankan sanksi pidana atas pelanggaran prinsip kerahasiaan bank ini berpariasi. Walaupun rahasia 
perbankan termasuk ranah pidana akan tetapi tidak menutup kemungkinan nasabah dapat menggugat secara perdata terhadap bank yang dengan sengaja membuka rahasia perbankan sebab keterangan mengenai nasabah yang merupakan keterangan yang harus dirahasiakan. Sebaliknya, meskipun tidak ada perjanjian antara bank dan nasabah, bank tetap berkewajiban untuk mempertahankan rahasia bank berdasarkan pada peraturan perundangundangan atau konsep hukum lainnya, seperti konsep perbuatan melawan hukum pasal 1365 KUHPerdata. Untuk hal ini nasabah harus dapat membuktikan bahwa kerugian yang dialaminya sebagai akibat dari pembocoran rahasia bank tersebut. Akan tetapi dalam Pasal 41, Pasal 41A, Pasal 42, Pasal 43, Pasal 44, Pasal 44A, dan Peraturan Bank Indonesia Nomor: 2/19/Pbi/2000 pada Pasal 2 ayat (4) rahasia perbankan dapat dibuka yang dengan ketentuan:

a. Kepentingan Perpajakan;

b. Penyelesaian piutang Bank yang sudah diserahkan kepada Badan Urusan Piutang dan Lelang Negara/Panitia Urusan Piutang Negara;

c. Kepentingan peradilan dalam perkara pidana;

d. Kepentingan peradilan dalam perkara perdata antara bank dengan nasabah;

e. Tukar menukar informasi antar bank;

f. Permintaan, persetujuan atau kuasa dari nasabah penyimpanan yang dibuat secara tertulis;

g. Permintaan ahli waris yang sah dari nasabah penyimpan yang telah meninggal.

Untuk kepentingan di atas informasi mengenai nasabah dapat dibuka dan bahkan di Pasal 47A Undang-Undang Nomor 10 Tahun 1998 tentang Perbankan menetapkan bahwa kesengajaan tidak memberikan keterangan yang wajib dipebuhi sebagaimana dimaksud Pasal 42A, dan Pasal 44A merupakan perbuatan pidana yang diancam dengan pidana penjara dan denda. Selain ketujuh poin di atas pembukaan rahasia perbankan dapat dilakukan guna penyelidikan yang dilakukan Bapepam dan BPK (badan pemeriksa keuangan) sebagaimana dalam Pasal 101 Undang-Undang Pasar Modal memberi kemungkinan bahwa dalam rangka pelaksanaan penyidikan, Bapepam dengan permohonan izin dari Menteri Keuangan dapat memperoleh keterangan dari bank tentang keadaan keuangan tersangka pada bank sesuai dengan peraturan perundang-undangan dibidang perbankan, dan dalam melaksanakan tugasnya Badan Pemeriksa Keuangan berwenang meminta keterangan yang wajib diberikan oleh setiap orang, badan, instansi pemerintah atau badan swasta sepanjang tidak bertentangan dengan undang undang walaupun Undang Undang Perbankan tidak mengaturnya.

Selain hal-hal yang diatas rahasia perbankan tidak dapat dibuka lalu timbul pertanyaan bagaimana untuk sengketa harta bersama dalam kasus perceraian apakah rahasia perbankan dapat dibuka. Berkaitan dengan sengketa harta bersamadalam kasus perceraian terhadap tabungan nasabah pada bank yang dituntut pembagian karena termasuk dalam harta bersama Undang Undang Perbankan tidak mengaturnya, artinya walaupun tabungan nasabah tersebut termasuk dari bagian harta bersama akan tetapi bank tidak mempunyai kewenangan untuk memberikan informasi mengenai nasabah walaupun diminta untuk dibuka di depan pengadilan karena dalam peraturan perundang-undangan tidak ada satupun pasal yang membolehkan 
bank untuk membuka rahasia bank untuk sengketa harta bersama kecuali hal tersebut mendapat izin atau kuasa dari nasabah yang bersangkutan.

\section{RAHASIA BANK TERHADAP HARTA BERSAMA PADA MKRI NOMOR 64/PUU-X/2012}

Hubungan antara bank dan nasabah bermula dari suatu perjanjian dan diakhiri juga dengan perjanjian pada umumnya. Dalam hal ini bank dan nasabah memiliki hak maupun kewajiban yang sama. Sehingga masing-masing pihak memiliki kewajiban untuk menaati dan melaksanakan segala hak dan kewajiban yang sudah ditegaskan dalam perjanjian.Seperti kewajiban merahasiakan yang telah diatur dalam Undang-Undang Perbankan.

Namun kewajiban merahasiakan data-data mengenai nasabah sebagaimana dimaksud dalam Pasal 40 Undang Undang Perbankan dirasa kurang memenuhi rasa keadilan bagi seseorang yang hendak menuntut haknya atas harta yang timbul dalam perkawinannya (harta bersama) undangundang tersebut dirasa hanya melindungi pihak nasabah saja karena bagi seseorang yang hendak menuntut haknya atas harta yang timbul dalam perkawinannya (harta bersama) mengalami kesulitan untuk mendapatkan informasi mengenai harta bersamanya yang hendak dituntut pembagian karena perceraian, sehingga MKRI dalam putusannya Nomor: 64/PUU-X/2012 atas uji materi Pasal 40 ayat (1) Undang Undang Nomor 10 tahun 1998 Tenatang Perbankan menyatakan:
1. Mengabulkan
permohonan pemohon atas uji materi Pasal 40 ayat (1) Undang-Undang Nomor

10 tahun 1998 Tentang Perbankan;

2. Pasal 40 ayat (1) Undang-Undang Nomor 10 tahun 1998 tentang Perubahan Atas Undang-Undang Nomor 7 tahun 1992 tentang Perbankan (Lembaran Negara Republik Indonesia Nomor 3790) adalah bertentangan dengan Undang-Undang Dasar Negara Republik Indonesia Tahun 1945 sepanjang tidak dimaknai termasuk untuk kepentingan peradilan mengenai harta bersma dalam perkara perceraian;

3. Pasal 40 ayat (1) Undang-Undang Nomor 10 tahun 1998 tentang Perubahan Atas Undang-Undang Nomor 7 tahun 1992 tentang Perbankan (Lembaran Negara Republik Indonesia Nomor 3790) tidak mempunyai kekuatan hukum mengikat sepanjang tidak dimaknai termasuk untuk kepentingan peradilan mengenai harta bersama dalam perkara perceraian.

Alasan hukum MKRI dalam putusan tersebut yaitu: "Bahwa Pasal 28G ayat (1) Undang-Undang Dasar 1945 menyatakan, setiap orang berhak atas perlindungan diri pribadi, keluarga, kehormatan, martabat, dan harta benda yang di bawah kekuasaannya, serta berhak atas rasa aman dan perlindungan dari ancaman ketakutan untuk berbuat atau tidak berbuat sesuatu yangmerupakan hak asasi, dan Pasal 28H ayat (4) Undang-Undang Dasar 1945 menyatakan, setiap orang berhak mempunyai hak milik pribadi dan hak tersebut tidak boleh diambil alih secara sewenang-wenang oleh siapapun. Dari ketentuan tersebut, maka setiap orang berhak atas perlindungan harta benda yang di bawah kekuasannya dan setiap orang memiliki hak milik pribadi yang 
tidak boleh diambil alih secara sewenang-wenang oleh siapapun.Kemudian Pasal 1 huruf $\mathrm{f}$ Kompilasi Hukum Islam yang berlaku berdasarkan Intruksi Presiden (Inpres) Nomor 1 Tahun 1991 menyatakan, "harta kekayaan dalam perkawinan (harta bersama) yaitu harta yang diperoleh baik sendiri-sendiri atau bersama suami istri selama dalam ikatan perkawinan, tanpa mempersoalkan terdaftar atas nama siapapun." Oleh karena itu dengan mengacu kepada Undang-Undang Nomor 1 tahun 1974 tentang Perkawinan terutama Pasal 35 ayat (1), Pasal 36 ayat (1), Pasal 37 serta Inpres Nomor 1 Tahun 1991 tentang Kompilasi Hukum Islam pada Pasal 1huruf f maka terhadap seluruh tabungan, deposito, dan harta benda dan produk perbankan lainnya yang dimiliki dan disimpan di bank oleh suami dan atau istri, harta tersebut mempunyai kedudukan sebagai harta bersama yang dimiliki secara bersama-sama oleh suami dan atau istri, sehingga harta tersebut mempunyai kedudukan sebagai harta bersama yang dimiliki secara bersama-sama oleh suami atau istri.

Berdasarkan pertimbangan

tersebut menurut MKRI, harta bersama yang diperoleh selama pernikahan, termasuk harta yang disimpan oloeh suami dan/ atau istri di satu bank baik dalam bentuk tabungan, deposito, dan produk perbankan lainnya merupakan harta benda milik bersama suami istri yang dilindungi menurut Konstitusi. Bahwa setiap nasabah harus dilindungi kerahasiaan datanya oleh bank, sebagaimana ditentukan dalam Pasal 40 ayat (1) Undang-Undang Perbankan akan tetapi pasal tersebut juga memberikan pengecualian bahwa data nasabah juga dapat diakses untuk kepentingan perpajakan, penyelesaiaan piutang bank yang sudah diserahkan kepada Badan Urusan Piutang dan
Lelang Negara/Panitia Urusan Piutang Negara, kepentingan peradilan dalam perkara pidana, perkara perdata antar bank dengan nasabahnya, kepentingan tukar-menukar informasi antar bank, atas permintaan, persetujuan, atau kuasa dari nasabah penyimpan yang dibuat secara tertulis, dari pengecualian tersebut, terdapat norma yang membolehkan data nasabah dibuka atas perintah pengadilan, yaitu untuk perkara pidana dan perkara perdata antar bank dengan nasabahnya. Berdasarkan hal tersebut, menurut Mahkamah, akan lebih memenuhi rasa keadilan apabila data nasabah juga harus dibuka untuk kepentingan peradilan perdata terkait dengan harta bersama, karena harta bersama adalah harta milik bersama suami dan istri, sehingga suami dan/atau istri harus mendapat perlindungan atas haknya tersebut dan tidak boleh diambil alih secara sewenang-wenang oleh salah satu pihak. Hal demikian dijamin oleh Pasal 28G ayat (1) dan Pasal 28H ayat (4) Undang-Undang Dasar 1945.

Sebagaimana putusan peradilan pada umumnya putusan peradilan konstitusi di MKRI juga mempunyai akibat hukum. Untuk putusan pengujian undang-undang bentuk putusannya adalah declarator constitutief. Artinya putusan MKRI dapat menciptakan suatu keadaan hukum baru atau meniadakan suatu kedaan hukum karena putusan MKRI langsung memperoleh kekuatan hukum tetap sejak diucapkan dan tidak ada upaya hukum yang dapat ditempuh.

Sifat final dalam putusan Mahkamah Konstitusi dalam UndangUndang MKRI mencakup pula kekuatan hukum mengikat (final and binding). Secara teoritis, final bermakna putusan MKRI berkekuatan hukum tetap setelah selesai diucapkan dalam sidang yang terbuka untuk umum dan tidak terdapat upaya hukum yang dapat ditempuh terhadap putusan itu. Sifat mengikat 
bermakna putusan MKRI tidak hanya berlaku bagi para pihak tetapi bagi seluruh masyarakat Indonesia.

Maka berdasarkan hal tersebut dengan adanya putusan MKRI Nomor: 64/PUU-X/2012 penerapan rahasia perbankan berubah yang mana dalam undang-undang perbankan sebelum adanya putusan Mahkamah konstitusi tersebut bank tidak dapat membuka informasi mengenai nasabah dan simpanannya pada bank di muka persidangan pada sengketa pembagian harta bersama akan tetapi setelah adanya putusan MKRI Nomor: 64/PUU-X/2012 pengecualian sebagaimana dimaksud dalam Pasal 41, Pasal 41A, Pasal 42, Pasal 43, Pasal 44, Pasal 44A Undang-Undang Nomor 10 tahun 1998 tentang Perbankan menjadi bertambah yaitu untuk kepentingan peradilan mengenai harta bersama.

Dalam hubungan kontraktual antara bank dan nasabah penerapannya juga berubah setelah adanya putusan MKRI Nomor: 64/PUU-X/2012 walaupun dalam formulir yang berisi perjanjian baku dengan klausula melarang bank untuk mengungkapkan keterangan mengenai nasabah akan tetapi pihak bank tidak dapat mematuhi klausula tersebut menyangkut sengketa harta bersama walaupun dalam Asas kebebasan berkontrak setiap orang leluasa membuat perjanjian apa saja akan tetapi keleluasaan itu tidak melanggar undang-undang dimana syarat sah perjanjian atau kontrak pada Pasal 1320 KUHPerdata menentukan empat syarat yang terdapat pada setiap perjanjian atau kontrak, dengan dipenuhinya syarat-syarat tersebut maka suatu perjanjian dapat berlaku sah. Adapun keempat syarat tersebut adalah:

1. Sepakat mereka mengikatkan dirinya;

2. Kecakapan untuk membuat suatu perikatan;
3. Suatu hal tertentu;

4. Suatu sebab yang halal. Syarat-syarat perjanjian sebagaimana tersebut di atas, meliputi syarat subyektif dan syarat obyektif. Apabila perjanjian tidak sesuai dengan syarat subyektif pada angka 1 dan angka 2, maka perjanjian tersebut dapat dibatalkan. Dan apabila perjanjian tidak sesuai dengan syarat obyektif pada angka 3 dan angka 4, maka perjanjian tersebut batal demi hukum. Maksud suatu sebab yang halal pada angka 4 bahwa perjanjian tersebut tidak boleh bertentangan dengan undang-undang apabila suatu perjanjian bertentangan dengan undang-undang maka akibatnya perjanjian tersebut harus batal demi hukum. Maka hubungan kontraktual antara bank dan nasabah dalam formulir yang berisi perjanjian baku dengan klausula melarang bank untuk mengungkapkan keterangan mengenai nasabah penerapannya juga harus sesuai dengan isi Putusan MKRI Nomor: 64/PUU-X/2012 karena sejak adanya putusan tersebut Pasal 40 Undang Undang Perbankan secara otomatis isinya berubah sesuai dengan isi putusan MKRI hasil uji materi undang undang perbankan tersebut.

\section{KESIMPULAN DAN SARAN}

\section{Kesimpulan}

Adanya hubungan hukum antara bank dan nasabah, bank mempunyai kewajiban untuk merahasiakan informasi mengenai nasabah, kewajiban tersebut muncul dari kontraktual antara bank dengan nasabah dan juga rahasia bank karena perintah undang-undang. Adapun pengecualian tidak membebaskan bank dapat membuka informasi data nasabah secara bebas ada prosedur atau tata cara yang harus diikuti. Dalam Undang Undang 
Perbankan menyangkut harta bersama, bank tetap tidak dapat membuka informasi walaupun dibuka di depan persidangan karena dari hubungan kontraktual ataupun undang undang tidak ada satupun bunyi klausula ataupun pasal yang membolehkan bank membuka informasi nasabah dimuka sidang sengketa harta bersama. Akan tetapi dengan adanya aturan hukum baru maka ketentuan rahasia bank menyangkut harta bersama sesuai dengan putusan Mahkamah Konstitusi Republik Indonesia Nomor: 64/PUU$\mathrm{X} / 2012$ dapat dibuka karena berdasarkan isi putusan MKRI tersebut Pasal 40 ayat (1) Undang-Undang Nomor 10 Tahun 1998 tentang Perbankan dinyatakan bertentangan dengan UUD 1945 sepanjang tidak dimaknai termasuk untuk kepentingan peradilan mengenai harta bersama dalam perkara perceraian.

\section{Saran}

Pemerintah dan DPR hendaknya merevisi rumusan Pasal 40 ayat (1) Undang-Undang Nomor 10 Tahun 1998 Tentang Perbankan, yang semula hanya 2 (dua) ayat menjadi 3 (tiga) ayat dengan menambahkan satu ayat ke (3) yang berbunyi: ketentuan sebagaimana dimaksud dalam ayat (1) dapat dikecualikan jika untuk kepentingan peradilan mengenai harta bersama dalam perkara perceraian.

\section{DAFTAR PUSTAKA}

Ali, Zainuddin., Metode Penelitian Hukum, Sinar Grafika, Jakarta: 2011.

Djumhana, Muhammad., Hukum Perbankan di Indonesia, Citra Aditya Bakti, Bandung, 1996.

Inpres Nomor 1 Tahun 1991 tentang Kompilasi Hukum Islam.
Judisseno dan Rimsky K, Sistem Moneter dan Perbankan di Indonesia, Gramedia Pustaka Utama, Jakarta: 2002.

Huala, Adolf., Hukum Perdagangan Internasional, Raja Grafindo Persada, Jakarta: 2004.

Kasmir, Dasar-Dasar Perbankan, Raja Grafindo Persada, Jakarta: 2002.

Kitab Undang Undang Hukum Perdata.

Mahmudin, Kamus Besar Bahasa Indonesia, Pusat Pembinaan dan Pengembangan Bahasa Departemmen Pendidikan dan kebudayaan, Balai Pustaka, Jakarta: 1995.

Marzuki, Peter Mahmud., Penelitian Hukum Kencana, Jakarta: 2006.

Marpaung, Leden., Pemberantasan Dan Pencegahan Tindak Pidana Terhadap Perbankan, Djambatan, Jakarata: 2003.

Putusan Mahkamah Konstitusi Republik Indonesia Nomor 64/PUU$\mathrm{X} / 2012$.

Undang-Undang Dasar Negara Republik Indonesia Tahun 1945.

Undang Undang Nomor 10 tahun 1998 tentang Perubahan Atas Undang Undang Nomor 7 tahun 1992 tentang Perbankan.

Undang-Undang Nomor 1 tahun 1974 tentang Perkawinan.

Usman, Rachmadi., Aspek-Aspek Hukum Perbankan Indonesia, Gramedia Pustaka Utama, Jakarta: 2001.

Undang Undang Republik Indonesia Nomor 8 tahun 2011 tentang Perubahan Atas Undang Undang Nomor 24 tahun 2003 tentang Mahkamah Konstitusi Republik Indonesia. 
Sastrawidjaja, Man Suparman., Perjanjian Baku Dalam Aktivitas Dunia Maya, Proyek Elips, Jakarta, 2002.

Sembiring, Rosnidar., Hukum Keluarga Harta-harta dalam Perkawinan, Raja Grafindo Persada, Jakarta: 2016.

Sunggono Bambang, Metologi Penelitian Hukum, Raja Grafindo Persada, Jakarta: 2003.

Sutedi Andrian, Hukum Perbankan suatu Tinjauan Pencucian Uang
Merger likuidasi dan kepailitan, Sinar Grafika, Jakarta, 2008.

Thalib, Sayuti., Hukum Kekeluargaan Indonesia, Universitas Indonesia, Jakarta: 1974.

Widiyono, Try., Aspek Hukum Operasional Transaksi Produk Perbankan Indonesia simpanan Jasa dan Perbankan, Ghalia Indonesia, Jakarta: 2006. 